\title{
CORRECTION
}

\section{Correction to: Measurement of Tungsten Carbide Tool Wear by Tribological Investigations}

\author{
P. K. Ambadekar ${ }^{1,2} \cdot$ C. M. Choudhari ${ }^{3}$
}

Published online: 22 April 2020

(c) Springer Nature Switzerland AG 2020

\section{Correction to: \\ Journal of Bio- and Tribo-Corrosion (2020) 6:44 \\ https://doi.org/10.1007/s40735-020-00337-y}

In the original article C. M. Choudhari's middle initial is incorrect. It is correct as reflected here.

Publisher's Note Springer Nature remains neutral with regard to jurisdictional claims in published maps and institutional affiliations.

The original article can be found online at https://doi.org/10.1007/ s40735-020-00337-y.

P. K. Ambadekar

pkaspa2018@gmail.com

1 Department of Mechanical Engineering, SIES Graduate School of Technology, Mumbai, India

2 Department of Mechanical Engineering, Father Conceicao Rodrigues Institute of Technology, Mumbai, India

3 Department of Mechanical Engineering, Terna Engineering College, Nerul, Mumbai, India 